\title{
As narrativas de jovens estudantes: travessia, acolhimento, simbolismo
}

Narratives by young students: crossing, welcoming, symbolism

\section{Las narrativas de los jóvenes estudiantes:}

travesía, acogimiento, simbolismo

\section{IDUINA MONT'ALVERNE CHAVES*}

Universidade Federal Fluminense, Niteroi-RJ, Brasil.

MÁRCIO MÓRI MARQUES**

Centro Universitário Carioca, Rio de Janeiro-RJ, Brasil.

GILMAR OLIVEIRA SILVA

Universidade Federal Fluminense, Niteroi-RJ, Brasil.

\begin{abstract}
RESUMO: O objetivo deste estudo é o de mostrar como a pesquisa narrativa promove o autoconhecimento e a reflexão em estudantes universitários, favorecendo a construção de um ambiente em que as relações docente-discente se estreitem e capturando os sentidos elaborados por eles ao narrar sua vida estudantil. O estudo está ancorado no paradigma da complexidade, de Edgar Morin, nos estudos antropológicos do imaginário, de Gilbert Durand, Hilmann, nas pesquisas de Christine Delory-Momberger, Bruner, Maria da Conceição Passeggi,
\end{abstract}

* Graduada em Pedagogia pela Universidade Estadual do Ceará e doutora em Educação pela Universidade de São Paulo. Atualmente é professora da Universidade Federal Fluminense. E-mail: <iduina@globo.com>.

** Graduado em Letras (Língua Inglesa) pela Faculdade Salesiana de Filosofia, Ciências e Letras - Lorena e mestre em Educação pela Universidade Estácio de Sá; doutor em Educação pela Universidade Federal Fluminense. Atualmente, é professor do Centro Universitário Carioca e mediador a distância da Fundação Centro de Ciências e Educação do Estado do Rio de Janeiro, onde já foi professor conteudista. E-mail: <profmarciomori@ gmail.com>.

*** Graduado em Educação Artística (artes cênicas) e em Educação Física. É mestre em Artes Cênicas pela Universidade Federal do Estado do Rio de Janeiro e doutor em Educação pela Universidade Federal Fluminense. Atualmente é docente na Universidade Federal Fluminense, com lotação no Colégio Universitário Geraldo Reis. E-mail: <gilmaroli@gmail.com>. 
Chaves, entre outros. A pesquisa narrativa promove o acolhimento e (des)venda o universo simbólico do alunato, auxiliando o saber sobre si e o estabelecimento de relações interpessoais. A pesquisa narrativa abre a possibilidade do diálogo estreito com a experiência viva, com a formação e o desenvolvimento pessoal, conforme se observa neste texto sobre a escuta sensível que se manifesta nas histórias contadas por três estudantes.

Palavras-chave: Formação. Pesquisa narrativa. Experiência viva. Simbolismo.

\begin{abstract}
The objective of this study is to show that, and how, the narrative research promotes self-knowledge and reflection in university students, favoring the construction of an environment in which the teacher-student relations become closer, and capturing the meanings elaborated by them when narrating their lives as students. The study is anchored in the complexity paradigm, by Edgar Morin, in the anthropological studies of the imaginary, by Gilbert Durand, Hilmann, in the research by Christine Delory-Momberger, Bruner, Maria da Conceição Passeggi, Chaves, among others. Narrative research promotes the welcoming and symbolic unraveling of students by assisting them on their self-knowledge, and helping them on establishing interpersonal relationships. Narrative research opens up the possibility of a close dialogue with living experience, with training, and personal development, as noted in this text about the sensitive listening that is manifested in the stories told by three students.

Keywords: Formation. Narrative research. Living experience. Symbolism.
\end{abstract}

RESUMEN: El objetivo de este estudio es mostrar qué y cómo la investigación narrativa promueve el autoconocimiento y la reflexión en los estudiantes universitarios, favoreciendo la construcción de un entorno en el que las relaciones profesor-alumno sean más cercanas y captando los significados que ellos elaboran al narrar su vida estudiantil. El estudio está anclado en el paradigma de la complejidad, de Edgar Morin, en los estudios antropológicos del imaginario, de Gilbert Durand, Hilmann, en la investigación de Christine DeloryMomberger, Bruner, Maria da Conceição Passeggi, Chaves, entre otros. La investigación narrativa promueve el acogimiento y (des)cubrir el 
universo simbólico de los estudiantes, ayudándolos a aprender sobre sí mismos y a establecer relaciones interpersonales. La investigación narrativa abre la posibilidad de un diálogo cercano con la experiencia viva, con la formación y el desarrollo personal, como se observa en este texto sobre la escucha sensible que se manifiesta en las historias contadas por tres estudiantes.

Palabras clave: Formación. Investigación narrativa. Experiencia viva. Simbolismo.

\section{Introdução}

Depois, mal o sol acabou de nascer, o homem e a mulher foram pintar na proa do barco, de um lado e de outro, em letras brancas, o nome que faltava ainda dar à caravela. Pela hora do meio-dia, com a maré, A Ilha Desconhecida fez-se enfim ao mar, à procura de si mesma. José Saramago, 1999.

narrativa autobiográfica fornece condições para adentrar no universo simbólico
de quem a narra, (re)velando as ideias-força contidas nesse ato repleto de sig-
nificados. As ideias-força são formadas por um grupo de palavras ou somente por uma palavra que, em consonância com o sentido total do discurso, (des)venda o que é e está subjacente, (des)cobrindo o que é pregnante e fazendo emergir o que está oculto, $\mathrm{o}$ que está esmagado nas entrelinhas. Evidentemente, podemos afirmar que, para desvelar o que está submerso, para imergir no imaginário, que é uma linguagem essencialmente metafórica, poética, hermética, codificada, não se pode ter pressa, tampouco compreender essa linguagem com o pensamento racional (DUCHASTEL, 2010, p. 54).

Na imersão no imaginário, cabe aqui um aparte. É mister convocar o pensamento durandiano, abordando os dois regimes da imagem: o Regime Diurno e o Regime Noturno da imagem. O Regime Diurno é relacionado à dominante postural, à tecnologia das armas, à sociologia do soberano mago e guerreiro, aos rituais de elevação e purificação" (DURAND, 2002, p. 68). Sob o signo da conversão e do eufemismo está o Regime Noturno, cujos símbolos são a descida ou a interiorização e a taça ou os utensílios continentes (DURAND, 2002, p. 199).

A autobiografia "é um relato feito por um narrador no aqui e agora, sobre um protagonista que tem o seu nome e existiu num passado, desembocando a história no presente, quando o protagonista se funde com o narrador" (BRUNER, 2008, p. 149).

A narrativa autobiográfica permite conhecer o alunato e estabelecer relações mais estreitas, haja vista que as pessoas gostam de ser ouvidas, o que é fundamental para o fortalecimento de relações interpessoais, pois o ouvir traz consigo consequências: gratidão, liberdade e o fato de promover um possível e rápido acesso ao processo de mudança 
(ROGERS, 1977). Mudança que pode conduzir o sujeito a uma vida harmônica, que pode estreitar a relação com o si-mesmo, promovendo a reflexão e o acolhimento.

Assim, pela hora do meio-dia, decifrando e desvendando o que está na superfície e o que está submerso nessa linguagem, e, principalmente, acatando o fato de que não podemos tudo compreender, tudo descobrir, "pela hora do meio-dia, com a maré" (SARAMAGO, 2013, p. 45), ir em busca de Ilhas Desconhecidas nos auxiliará a conhecermos o Outro e a nós mesmos nesse Outro.

\title{
Partida para as ilhas: as narrativas
}

\author{
Se partires um dia rumo a Ítaca \\ faz votos de que o caminho seja longo, \\ repleto de aventuras, repleto de saber. \\ Tem todo o tempo Ítaca na mente. \\ Estás predestinado ali chegar. \\ Mas não apresses a viagem nunca. \\ Melhor muitos anos levares de jornada \\ e fundeares na ilha velho enfim, \\ rico de quanto ganhaste no caminho, \\ sem esperar riquezas que Ítaca te desse. \\ Uma bela viagem deu-te Ítaca. \\ Sem ela não te ponhas a caminho. \\ Mais do que isso não the cumpre dar-te. \\ Ítaca não te iludiu, se a achas pobre. \\ Tu te tornaste sábio, um homem de experiência, \\ e agora sabes o que significam Ítacas \\ (KAVÁFIS, 1982, p.118-119.) $)^{1}$
}

Uma atividade que sempre realizamos ao iniciar nossas aulas no ensino superior é a de mapear a história de vida escolar dos alunos, no intuito de fazer uma sondagem sobre as passagens de fases, id est, do ensino fundamental para o ensino médio, e do ensino médio para a universidade. Para tal, utilizamo-nos da narrativa autobiográfica.

“É...", palavra quase sem tradução e que morre em nossos lábios, muitas vezes no decorrer de nossa prática, do fazer diário em meio à ventania e à calmaria, traz-nos certamente o espírito da espera no "aquífero semântico" (DURAND, 2002) que os achados da narrativa autobiográfica podem (re)velar. E nessa espera, haja vista que o processo não é ligeiro, aguardamos pelos resultados. A narrativa autobiográfica pode nos proporcionar valiosas experiências para conhecer os discentes e também para a sondagem da alma, do mundo que os alunos carregam, pois "nossas experiências vividas singularizam nosso destino" (MORIN, 2012, p. 33).

A autobiografia (existencial, filosófica, poética) que "leva em conta as fendas e o inacabado, é precisamente aquilo que permite se pensar em relação. Ser não de uma forma 
intangível, seguro de si mesmo, mas como um simples elemento de um arquipélago mais amplo" (MAFFESOLI, 2007, p. 161).

Adentrar no pequeno-grande-mundo que (re)vela o infinito museu do imaginário pode proporcionar reflexões: reflexões sobre a própria prática - ainda permeada pelo espanto -, sobre as nossas convicções e leituras sobre o papel da pedagogia, sobre a importância da relação professor-aluno, sobre o afeto - que, algumas vezes, se faz ausente, em face das exigências de um tempo em que tudo ocorre em velocidade exponencial.

E nesses tempos em que o vínculo social é realizado por meio de afinidades mais eletivas do que racionais

ter ou não ter 'feeling' será o critério essencial para julgar a qualidade de uma relação. E é nesse aspecto no mínimo evanescente que repousará sua durabilidade. Não surpreende, assim, que os humores pessoais e sociais constituam o cimento da vida social. Pathos. Thymos². Eis efetivamente o horizonte epistemológico no qual se movem a política, a geopolítica e até a economia (MAFFESOLI, 2007, p. 162).

Para irmos ao encontro, então, do pensamento maffesoliano, a seguir, apresentamos três autobiografias. Os nomes dos participantes são fictícios: como estamos a navegar, escolhemos o nome de três ilhas gregas: Ceos, Gavdos e Milos - até então desconhecidas.

\section{O ar em movimento - ventos fortes e calmaria}

Após mobilização em sala de aula, clarificamos que nesse momento havia a possibilidade de se ficar entorpecido por himma, que "é o modo pelo qual as imagens, que acreditamos criar, nos são apresentadas não como tendo sido criadas por nós, mas genuinamente criadas, como criaturas autênticas" (HILLMAN, 2010, p. 15).

Como epígrafe de sua narrativa, Ceos contou-nos que buscou uma frase nos vastos oceanos da internet e não nos forneceu a referência. Entre tantas frases disponíveis, escolheu o seguinte texto:

"Há três métodos para ganhar sabedoria: primeiro por reflexão, que é o mais nobre; segundo por imitação, que é o mais fácil; e terceiro, por experiência, que é o mais amargo - Confúcio" (CEOS).

Pela epígrafe, sentimos que estas palavras anunciariam os ventos que sobre ela abateram, pois a experiência, "é aquilo que nos passa, o que nos acontece e o que nos toca" (LARROSA, 2015, p. 18).

Assim ela iniciou a sua narração:

"Aqui no Rio de Janeiro, o sol pela manhã tinha um brilho diferente. Emitia seus raios luminosos e deixava tudo dourado e contente. As flores que caíam no chão da escola em todas as estações do ano eram grandes e amareladas. Pareciam feitas de tecido delicado" (CEOS). 
A descrição do cenário levou-nos a pensar em uma narrativa heroica, carregada de tons emocionais: sol, luminosidade e dourado. Isso nos remeteu ao Regime Diurno da imagem por conter esses símbolos. Importante destacar que a "ascensão é imaginada contra a queda e a luz contra as trevas", pois a luz - a luminosidade - tem a tendência para se tornar raio ou gládio e indica um sentimento de potência (DURAND, 2002, p. 158). Entretanto, logo a seguir, apareceram as folhas amarelecidas que caiam durante todo o ano, parecendo desobedecer às estações. Adentra-se, então, num momento que, aparentemente, revela o que está por vir: a luta. "Para o herói solar são sobretudo os efeitos que contam, mais que a submissão à ordem do destino" (DURAND, 2002, p. 159).

No que se refere à simbologia das folhas, elas participam do reino vegetal e podem ser um símbolo de felicidade ou também designar "o conjunto de uma coletividade, unida numa ação coletiva e num pensamento comum" (CHEVALIER e GHEERBRANTD, 2012, p. 44). Entretanto, mortas, amarelecidas, as folhas anunciam o que está por vir: um inverno com ventos fortes e constantes.

E proferiu:

"Aos sete anos, eu começava a primeira série do ensino fundamental. É perfeita a lembrança do meu primeiro dia de aula. A professora gritou comigo desnecessariamente por eu ter me esquecido de levar um bloco de papel A4 para ela. Quanta crueldade" (CEOS).

Logo na entrada, no primeiro dia, a decepção: gritos - ventos uivantes anunciavam o quase trágico, uma marca profunda. A professora - por ter algum motivo, o que é ignorado na narrativa da aluna - chamou-lhe a atenção com um grito. A professora poderia ter falado em voz alta, em meio a tantas crianças, mas o fato foi sentido de outra maneira, talvez. Entretanto, para a aluna, tratava-se de crueldade. O prazer de prejudicar o outro procede talvez da idolatria da certeza, do sentimento que o outro sentirá desprazer (ROSSET, 2002, p. 39), possivelmente. Mais adiante, proferiu o seguinte:

"Eu sempre fui uma criança recatada, muito tímidae, naquele momento, tive um sentimento terrivel, mas o guardei dentro de mim e tive vontade de chorar; porém, não chorei, embora estivesse com muita vontade" (CEOS).

Percebe-se o resquício de um sentimento de desprazer, tanto que o sentimento é denominado 'terrível'. E, mais um detalhe, a criança da época se apresentava como "recatada e tímida". Uma escola centrada na certeza, na técnica, pouco verifica isso, pois o sentir é desprivilegiado, uma escola em que ainda vigora o "penso, logo existo", ao invés de o "sinto, logo sou", e, ademais, "o mundo só se dá sob a forma do sensível"; ademais não há nada no espírito humano que não tenha passado, primeiramente, pelos sentidos (LE BRETTON, 2016, p.13-24). E os sentidos, comumente, não eram trabalhados nessa escola, principalmente, no que tange à expressão corporal. Assim, nada foi feito para que a timidez fosse afastada ou minimizada. 
Começa aí a trajetividade da heroína: a descida, a falta de força anímica. Vale destacar algumas palavras para descrever o início escolar:

"Nas primeiras aulas, eu somente copiava o que estava no quadro, coisas, signos e símbolos que eu não entendia o que significavam, eu apenas copiava. E, nos meus cadernos, aqueles traços tornavam-se garranchos indecifráveis. Com o passar do tempo, comecei a copiar palavras e a decodificá-las. Inconsciente ou consciente, comecei a ler; não me recordo se entendia o que lia, mas eu sabia ler" (CEOS).

No aprender a ler e escrever, observa-se a prevalência do ensino prescritivo, que objetiva levar o aluno a substituir seus próprios padrões de atividade linguística, considerados inaceitáveis, por outros, considerados corretos (HALLIDAY, McINTOSH e STREVENS, 1974). Portanto, o objetivo é levar o aluno a dominar a língua culta ou padrão, em detrimento da existência de outros falares, regionais, possíveis. Em outras palavras, um tipo de ensino que não permite que o discente faça a travessia entre o falar regional, popular, e o falar considerado culto, um ensino que não permite que o aluno seja bilíngue dentro de sua própria língua, o que concretiza a supremacia da racionalização. Outra prova disso é o fato de decodificar sílabas, mas não compreendê-las, não lhes dar significado.

E a narração sobre o ato de ler continuou no seguinte trecho, confirmando o tipo de ensino:

"Já no segundo ano, comecei a ler poemas nada complexos, pequenos textos e a responder a questões, tais como o título do texto ou do poema, as personagens, o número de versos, o número de parágrafos" (CEOS).

Esse trecho sobre o ato de ler apenas apresenta como dissecar um texto objetivamente, o que não pode promover a travessia do discente para o mundo do sentir, pois trata somente do lado objetivo, racional. A razão é importante, mas deve vir mesclada com a emoção - que se faz sempre ausente, nesse caso. O que se pode sentir ao ler um texto? Quantos mundos dentro de um mundo? O que se pode criar ou recriar a partir de uma leitura?

Isso nos pôs a pensar no que viria adiante, uma vez que já havia a previsão na narração do cenário: folhas amarelecidas, mortas. Assim, relatou:

"Meu pesadelo começou na terceira série: eu tinha pavor da professora. Eu não gostava de ir para a escola, tampouco de ver a professora. Como se não bastasse, depois dessa fase difícil, minha situação na escola começou a piorar. Era só o início de meus apuros" (CEOS).

Difícil pensar nas marcas deixadas na aluna, quando afirmou que o pesadelo havia começado e que sentia um pavor: pavor em relação à professora. E também pelo fato de não gostar mais de ir à escola. Triste fato. Dissecar as duas palavras, pavor e pesadelo, se faz necessário. Pavor nos remete à palavra terror, algo que assusta; pesadelo nos remete aos bastidores do sonho: sonho ruim, desagradável. Esse acontecimento nos mostra a 
importância da relação professor-aluno, pois a ausência de uma relação pode ser trágica e marcante. O professor muito pode fazer para que o aluno adentre o mundo do saber, da experiência, quando mescla inteligência e afeto. É importante "transformar a transmissão do saber num processo dramático e tão emocionante como a própria vida, quando ela é vivida corajosa, despojada e criativamente" (BYINGTON, 2003, p. 20).

Na construção do saber, é necessária a introdução do diálogo amoroso. Assim, cessa a sensação de pavor.

Quanto aos valores no caminhar, a aluna nos revelou que, no último ano do ensino fundamental, teve

\begin{abstract}
"o azar de ter uma 'turma do capeta'. Lembro-me de que, naquele ano, foram mais de três professores que passaram pela turma. Nenhum conseguiu ficar, e o que influenciou foi o comportamento da turma. Não havia respeito nem vontade de aprender. Certa vez, colaram um papel nas costas da professora com uns dizeres horrorosos. Acho que ela chorou e nunca mais voltou. Quando definitivamente ficávamos sem professor, éramos obrigados a ir para o pátio e permanecer presos na escola. Aí vinha a coordenadora e passava qualquer tarefa para nós fazermos - poucos faziam" (CEOS).
\end{abstract}

É fato que não houve um ensino para a compreensão, para o respeito ao outro. O excesso de racionalização pode levar a isso, pois é centrado em programas. E, nos programas, nas políticas públicas que orientam o ato educativo, não há menção a uma abertura em relação ao outro, tampouco uma interiorização da tolerância, o que reforça o egocentrismo; assim, é preciso inserir nesses programas que "compreender é também aprender a reaprender incessantemente" (MORIN, 2000, p. 102).

Mas o pavor antes citado reapareceu e foi acentuado no ano seguinte, já no ensino médio: ventos sombrios de um 'cárcere'. Assim, ela afirmou:

"O ensino médio foi o meu cárcere. As paredes da escola eram altíssimas. A iluminação era fraca a ponto de parecer mesmo um cárcere. O cenário era cinza, as paredes eram bem semelhantes às de cadeia, tijolinhos laranja pichados, nas escadarias não havia corrimão, as carteiras eram riscadas, os ventiladores de teto eram assustadores, pois a sensação de que um cairia sobre nós era constante. Ficava sempre quieta, sentada num canto" (CEOS).

A escola vista como cárcere é uma escola desalmada, fruto de um paradigma da simplificação, fruto de uma pedagogia da certeza, que navega na busca de porto seguro. Mas em um mundo em constante movimento, um mundo de incertezas, não há porto seguro (JAPIASSU, 1983). Certamente, era uma escola sem ternura, uma escola na qual havia promoção somente do racional em detrimento do sentir, uma escola em que o amar e brincar estavam ausentes. E mais: o sentar-se num canto passa a ideia de solidão. O canto é a marca de um negativismo, o local seguro, o local próximo da imobilidade, é um refúgio (BACHELARD, 1993, p. 146). E, de um refúgio, é possível assistir a todas as cenas da vida e delas não participar. Escolas desalmadas promovem a imobilidade, pois são cantos do mundo. 
No final, o último ano: uma comemoração. A trajetividade da heroína começou a se redesenhar. Nesse momento, ventos sombrios sopraram, e ela relatou: "No último ano, cheguei a comemorar, pois ficaria livre da prisão (CEOS)".

Importante destacar que "o puer não suporta a falta de direção com tempo e paciência. Não sabe quase nada das estações e da espera"; enfim, o puer não compreende a "complexidade labiríntica do mundo horizontal", que é o contínuo do tempo/espaço, denominado 'realidade'; o mundo do puer é vertical, do voo e da queda (HILLMAN, 1998, p. 38-39); no entanto, mesclado a esse esquema vertical, outro se apresentava: o intimista, o regime pleno do eufemismo.

Cabe lembrar que o Regime Noturno da imagem, oposto ao diurno, é "idêntico em força e coesão", promove "um suave retorno ao centro", por não combater o destino, mas assimilá-lo (TEIXEIRA e ARAÚJO, 2011, p. 51).

No que tange a esse regime, "a fantasia do Regime Noturno conservará da técnica polêmica a preocupação da couraça, a precaução da defesa e da ostentação" (DURAND, 2002, p. 200).

Importante destacar, nessa afirmação, a simbologia da palavra prisão, pois poucas coisas provocam tanto medo nos sujeitos como o pensamento da prisão, haja vista que "os seres vivos, desde a saída da semente, do ovo ou do útero, lutam inatamente pela liberdade" (MARTIN, 2012, p. 634). Será que nós, docentes, tantas vezes quixotescos, paramos para pensar nisso? Será que consideramos a escola somente como agente de libertação dos grilhões da ignorância?

Finalmente, após a queda, a ascensão, como em todo trajeto em que se manifesta a heroicidade. Ceos destacou uma frase esperançosa, que continha reflexão sobre o que se passou, entrevendo a sua situação escolar, os planos que seriam traçados, e o recebimento de um elogio:

“Ótimos professores eu tive. Em paralelo, comecei a estudar para o Enem. Fraca em matemática, comecei a pensar em fazer publicidade e propaganda. Certa vez, uma professora escreveu a seguinte frase no final de meu texto: - 'vale a pena cuidar do seu texto'. Apesar dos meus erros, ela escreveu isso (CEOS)".

Nesse ponto, ancoramo-nos no pensamento da complexidade, pois as experiências podem nos tornar incapazes para a vida ou, contrariamente, podem nos reforçar. Assim, percebemos um reforço, pois na trajetória, no caminhar, ela se deslocou entre os ventos, ora fortes, ora calmos, com uma intenção de superar as agruras - ventos de borrascas que sobre ela se abateram.

O reconhecimento por ter conhecido excelentes professores é um alento, pois é sabido como muitos profissionais são dedicados à própria missão: "uma tarefa de saúde pública"; principalmente, aqueles que compreendem a missão de transmissão em que o eros é indispensável em todo ensino, "que é, a um só tempo, desejo, prazer e amor; desejo e prazer de 
transmitir amor pelo conhecimento e amor pelos alunos - o eros permite ligar a fruição ligada ao poder, em benefício da fruição ligada à doação" (MORIN, 2000, p. 101-102). O final do relato, em que sopram bons ventos, em que se percebe a calmaria de movimentos, que se anuncia um desejo, uma vontade de adentrar no caminho, revela o poder de um elogio - em meio a uma paisagem que se desenhou cinzenta e, por vezes, nebulosa. Cabe destacar também a entrada num mundo horizontal, isto é, na realidade, despedindo-se lentamente do mundo vertical, que é o do voo e da queda.

E o vento levou... Levou experiências ruins, carregou para longe. E no 'se contar', ato de (re)fletir em voltas dentro de si própria, vimos Ceos flanando em outros ventos: ventos que levam sementes para a terra fértil do existir e rumar para a sua ilha.

\section{Gavdos: a calmaria e o navegar}

Gavdos iniciou a sua autobiografia de uma maneira tradicional, informando onde nasceu, quem eram os seus pais, a data do seu nascimento e anunciando todos os membros da família. Fez algo tradicional - como se não houvesse turbulências em sua vida, como se desejasse ser extremamente claro. Mostra a persona. Assim:

"Nasci no bairro Vinte e Cinco de Agosto, em Duque de Caxias, às 22 horas e 10 minutos. Filho de Marcela, neto de vó Aparecida e avô Josué; sobrinho de Mirela, Lourdes, Ana e Judith; sobrinho de Pérsio, Fabrício e Raphael, tios incisos. Desde o vigésimo sétimo dia do quarto mês de 1998, estou aqui, limitado, por enquanto, aos limites fluminenses. Após a saída da maternidade caxiense, fui levado à minha antiga e primeira casa, numa rua simples e reta, em São João de Meriti. São João de Meritié a cidade na qual moro, desde que dormi no meu primeiro berço. Meu sono inicial é ressaltado até mesmo após o momento em que escrevo esta linha, visto que eu durmo muito" (GAVDOS).

Gavdos, no espaço primeiro em que habitou, já se sentia preso: circunscrito, limitado aos limites fluminenses. "Limitado" aponta para desejos não realizados - "por enquanto" - acrescenta. Esse desejo de sair, de voar, de romper barreiras já estava presente desde o início do texto. Mas trouxe a impressão de que era algo para o futuro, o desejo agora não poderia ser satisfeito. Por enquanto, esse "limitado" é porque se sentia preso. Preso a limites, a correntes do limite, inferimos. Podemos afirmar, então, que "em um sentido sociopsicológico, a corrente simboliza a necessidade de uma adaptação à vida coletiva e à capacidade de integração ao grupo", pois tal símbolo "marca uma fase da evolução ou involução pessoais" e, sob o ponto de vista psíquico, não há nada de mais difícil do que sentir a indispensável ligação social não como uma corrente, mas "numa forma de adesão espontânea" (CHEVALIER e GHEERBRANT, 2012, p. 292-293). Por outro lado, esse "limitado" pode remeter também ao além-mar. O mar é o limite. O mar é o "lugar dos nascimentos, das transformações e dos renascimentos" e simboliza "uma situação de 
ambivalência, que é a de incerteza, de dúvida, de indecisão, e que pode se concluir bem ou mal" (CHEVALIER e GHEERBRANT, 2012, p. 592).

Da família, destacou o amor pela avó materna:

"Sobre os primeiros anos, foi o início de uma grande versão da guia minha e para além dos limites parentais: minha avó. Lembro-me de que os seus colos moles e estáveis adormeciam o meu choro - quando eu chorava demais. Minha vó tinha um tão estável colo, que, mesmo ela em outra realidade e incerteza para mim, eu ainda recorro a ela" (GAVDOS).

A guia, a avó, trouxe os fios, que "segundo o Zohar", é um dos símbolos mais antigos, como o cabelo. O fio simboliza a conexão essencial, em qualquer dos planos: espiritual, biológico, social", entre outros (CIRLOT, 1984, p. 255). Como Ariadne, a avó, a Grande Mãe, deu-lhe armas para enfrentar os "minotauros" da vida e o fio condutor para desbravar o viver. $\mathrm{O}$ aconchego (os colos moles e estáveis, os quais adormeciam o choramingar) era como um trono. Cabe lembrar que "o trono original é o colo da Grande Mãe, o útero imaginário e infinito da natureza no qual tudo é concebido [...] e também vale destacar que as representações neolíticas da Grande Mãe "realçam a vastidão de seu colo e sua capacidade para suportar, abranger, estabilizar, confortar, segurar e segurar com força" (MARTIN, 2012, p. 586)". A avó representa o conforto, a estabilidade, a Grande Mãe.

Vasculhando a memória, afirmou que, antes do ensino fundamental, no chamado Jardim, frequentado dos três aos seis anos, mostrou-se uma criança diferente,

"no ensino fundamental, uma boa criança eu fui: fiz meus deveres, obedeci à professora, nem tantos amiguinhos eu fiz e, não sei por quê, não me segurei o controlável - a professora amenizou-me" (GAVDOS).

A boa criança, cumpridora dos deveres e obediente, já se revelava na infância. Descreveu-se como uma criança diferente em meio às outras, pois chamou-se de "insatisfeito":

"Entre os três e seis anos, foi um periodo de muitíssimos aprendizados: moderadas brincadeiras feitas, uma leve visão sobre a particularidade local e moderadas referências visuais para um insatisfeito. Um cotidiano simples e único, uma vez que o local era propício para meninos agitados, para muita pipa, muita bicicleta e muito gude. Eu fui um observador pelo mérito da negação das outras crianças que faziam: por não ser ágil, sobre" (GAVDOS).

Como charada, fez inversões na escrita - revelando um certo hermetismo - pois, refazendo a frase, teríamos: faziam ('as outras crianças') coisas que eu não fazia, isto é, brincar em excesso, por não ser ágil - feito a ações que não revelavam rebeldia, por ser contido e obediente - não expressava movimentos próprios de criança. Daí a negação.

Cronologicamente, mas não informando sobre o primeiro dia de aula, sobre os professores, sobre a experiência no ensino fundamental, deu um salto e contou alguns fatos já na terceira série: 
"Já no terceiro ano, as coisas foram diferentes: foi o avesso do que os anteriores foram em dezembro de 2006, minha primeira mudança de casa. Ainda em São João, saio do Duque e vou ao Paraíso - que evolução! Lá, a minha cabeça tem um "boom" de novos métodos. Minha avó, ainda presente e persistente, me guiava, e guiava, e guiava. Estudei, na terceira e quarta série, em um moderado colégio - hoje falido -, fui perdendo os amigos da rua em linha reta e conheci novos que, novamente, perdi. Tornei-me mais pacato, talvez por morar em uma avenida não passiva com as brincadeiras, embora houvesse algumas esporádicas, como soltar pipa - odeio pipa" (GAVDOS).

Não era afeito ao brincar em grupo. E forneceu uma imagem dessa época: a pipa que, comumente, as crianças brincam em grupo. E quem dirige a pipa é o vento, símbolo da inconstância, da instabilidade e "entre os gregos, os ventos eram divindades inquietas e turbulentas, contidas nas profundas cavernas das Ilhas Eólias"; quanto à simbologia da pipa, também chamada de papagaio, é mister salientar que "o papagaio de empinar (fr. Cerf-volant, literalmente, cervo voador) faz lembrar a grande lei físico-química que dá ao cervo-Mercúrio a possibilidade de elevar-se e propicia a realização da sublimação filosófica", pois o cervo é retratado, em algumas obras de arte, como "o símbolo do temperamento melancólico, sem dúvida, por causa de seu gosto pela solidão" (CHEVALIER e GHEERBRANT, 2012, p. 935). Mas uma outra interpretação nos leva a crer que se trata também de um comportamento prudente: "escritores e artistas têm feito do cervo um símbolo de prudência, porque ele foge sempre no sentido do vento que leva consigo seu cheiro" (CHEVALIER e GHEERBRANT, 2012, p. 226). Melancólico, prudente e solitárioassim já se mostrava nos anos iniciais da sua aventura acadêmica.

Com mais um salto na sua narrativa, narrou a sua entrada no ensino médio:

"Estudei, em São João de Meriti. O colégio, escola pública, é bem localizado, é um colégio bastante requisitado pelos pais que, geralmente, colocam seus filhos lá, no momento da inscrição "online", o escolhem como prioridade de estudo para seus filhos. O que mais me atraiu atenção, à primeira vista, em 2013, no meu primeiro ano do ensino médio, foi a boa estrutura externa do local. Tinha a impressão de que era um colégio que se encaminhava pelas tabelas como qualquer outro colégio público. Porém, ao conhecer aos poucos a realidade da instituição, eu pude notar que grande parte da minha impressão acerca da qualidade do ensino público era infundada e baseada na generalização, permitida por mim, que o tempo me proporcionou" (GAVDOS).

As impressões generalizadas sobre a escola pública, oriundas do senso comum, pois comparada sempre aos colégios de prestígio social, é perceptível ao afirmar que:

"um colégio que se encaminhava pelas tabelas como qualquer outro colégio público. Durante os três anos em que lá estudei, vi bastante greve, desrespeito de alunos, desorganização nossa (aluno) e grandes muros; no entanto também vi um ótimo e bem abastecido refeitório, diversificada biblioteca, uma boa coordenação, ótimos professores e também uma ótima diretora.A estrutura docente, muitas vezes, não desfazia ou amenizava algum problema, a equipe é uma ótima construtora. Um exemplo grandioso do sucesso do colégio e da diretora Regina é o grupo de dança e teatro, no qual tive grande felicidade de participar. Confesso que é difícil delinear os prós e contras do local, visto que eu nunca tive contato próximo com os gestores do colégio e pela complexidade do meio escolar fluminense e brasileiro" (GAVDOS). 
Mas a imagem ruim foi desfeita, e Gavdos salientou que a sua opinião era infundada. Esse reconhecimento posterior ou já sentido à época demonstra o início da chegada de um amadurecimento, pois esse raciocínio é crítico, contém discernimento. Interessante descobrir que nessa escola havia aulas de teatro, o que deve ter dado ao discente armas para se livrar da timidez, da melancolia, enfim, deve tê-lo colocado para aprender a trabalhar em grupo, pois a arte é capaz de trazer mudanças. A vivência nesse local proporcionou a ele um novo olhar, mesmo em face de problemas corriqueiros - enfrentados pela criança eterna em busca de autoafirmação. Mas, em momento algum, vemo-lo numa situação em que o desrespeito impera - não há relatos sobre isso, pois ele apontou para outros que participavam desses atos.

Vale lembrar que há uma referência a uma coisa comum nas escolas públicas: o muro. Mas esse muro, para ele, além de ser o muro físico, é o muro que impedirá outros de fazer uma travessia.

Sobre o ensino médio

"também confesso que somente o ensino que tive na escola em que estudei não me permitiu
a segurança do ingresso ao ensino superior, embora eu tenha ingressado em uma - muitos
até recorreram, recorrem e recorrerão aos inúmeros cursinhos preparatórios. A insegurança
em relação ao ingresso no ensino superior, para mim, ocorreu por diversos motivos que
podem ser confundidos como único: houve muitas greves; a nossa falta de seriedade em
algumas matérias, sobretudo as que não reprovam, como educação física, sociologia, filo-
sofia (todas as referidas somente tinham um tempo na semana!); a nossa incerteza diante
do futuro - quando escolhemos um curso do ensino superior, o encaminhamento pessoal é
melhor orientado, visto que temos uma plena e, às vezes, rala noção sobre a área escolhida.
Na escola, muitas vezes e nem sempre, íamos por ir -; e até mesmo a falta de seriedade dos
pais" (GAVDOS).

Outra vez mencionou o "muro" - o que impedirá os alunos de ingressar no ensino superior - e abordou a insegurança, a própria insegurança, o medo de fazer a travessia. Medo dos outros muros. O muro, além de ser a separação entre os outros e o eu, "é a comunicação cortada, com a sua dupla incidência psicológica: segurança, sufocação; defesa, mas prisão (CHEVALIER e GHEERBRANT, 2012, p. 626)”. Para Gavdos, o muro revelava a separação, mas ficou implícito também o fato de sufocar. Como aluno estudioso, reclamou das poucas aulas de filosofia e sociologia, e não demonstrou tanto interesse pelas aulas de educação física. Cabe lembrar que a aula de filosofia "é esse momento privilegiado numa existência em que o espaço mental se alarga até coincidir com o espaço vital inteiro" e é importante destacar que "à crise da adolescência, a aula de Filosofia propõe a solução da aventura e as disciplinas do espírito" (GUSDORF, 2003, p. 252). Gavdos é consciente de que o pensar é importante e que essas aulas poderiam fazer dele um ser humano mais consciente e mais competente.

Em síntese, resumiu os três anos do ensino médio 


\begin{abstract}
"sintetizando as minhas emoções e impressões colegiais, posso dizer que lá é um bom lugar para estudo e convívio; porém, para realmente aproveitar o ensino oferecido, serão precisos muitíssima concentração durante o triênio e o desenvolvimento de uma aptidão autodidata e persistente" (GAVDOS).
\end{abstract}

De uma forma madura, afirmou que o ensino médio foi um local de estudo e fez uma ressalva, aludindo ao fato da necessidade de os alunos terem concentração e de serem persistentes. O conselho, obviamente, foi dado e seguido por ele.

Sobre as boas lembranças desse período, afirmou:

\begin{abstract}
"o conjunto do segundo ano foi o que mais me marcou positivamente, pois foi o auge de muitas amizades que fiz - pena que eu não vejo alguns amigos há mais de um ano. Uma outra lembrança boa é referente aos momentos em que eu encontrava, antes das aulas matinais, no primeiro ano, o Santana (um grande amigo): ele vinha pela rua do bar do China e acenava que nem um louco para mim, enquanto eu o esperava (e me agitava feito um louco) no ponto do ônibus" (GAVDOS).
\end{abstract}

No ensino médio, houve socialização: o menino que não brincava em grupo, passou a ter alguns amigos.

No que tange à entrada na universidade, ressaltou:

"[...] no dia 27 de dezembro de 2015, foi um dia rápido e sucinto: a morte da minha avó e nada mais. 2016 foi o reforço da minha pacatez e o ingresso para a faculdade. Indo ao Rio Comprido constantemente, tive outro intenso e ascendente boom visual, pois eu conheci grande parte do Rio de Janeiro e tornei-me um conhecedor moderado das ruas e rotas de ônibus cariocas andar de ônibus é a minha principal diversão. 2018 ainda é um ano incerto, meus objetivos estão sendo encaminhados com simplíssimas felicidades. Eu tenho felicidades simplíssimas e duradouras (GAVDOS)".

A entrada para a faculdade e a morte da avó, a Grande Mãe, foram os fatos marcantes dessa época. Como pacato, ele se define. A tristeza retorna, e ele diz ter alegrias, felicidade nas coisas simples, comuns.

Sobre as disciplinas prediletas informou-nos que

"a disciplina de português sempre me atraiu. Nos três anos, eu tive boas professoras da matéria que clarearam a minha mente com aprendizados sobre a forma da expressão. Artes também está na minha predileção, uma matéria riquíssima. Foram as minhas principais oportunidades de enxergar o mundo muito além da comunidade - foram séculos, nações, amores..." (GAVDOS).

O fato de gostar de se comunicar bem, por meio da escrita, da poesia e apreciar as artes se fez presente na vida de Gavdos, e podemos inferir que as simples alegrias advêm desse fazer: o poético invadindo a alma e trazendo um equilíbrio, fazendo-o ver o mundo com outros olhares - nem tanto tristes.

No que se refere ao relacionamento com os professores, respondeu-nos que "era miúdo e respeitoso". A boa educação recebida pela família fez com que tivesse um 
relacionamento respeitoso com os professores, mas antes do "respeitoso" vem a palavra miúdo, que pode ser de pequenas proporções. Esse miúdo também pode ser interpretado como delicado, algo pequeno que tem de ser cuidado para não se quebrar. Como ele é apreciador de poesia, acreditamos que esse miúdo é delicado, algo que não se pode quebrar, um pequeno frasco de cristal, contendo os mais suaves perfumes.

\section{O contraste - movimento das águas}

Milos gosta de silêncios. Pouco falou e escreveu o necessário. Ficava sempre a observar os outros, como se estivesse jogando xadrez, para depois mover as peças.

Aparentemente, é um navegante que, na calmaria, pesca sonhos e observa a movimentação das águas, águas do real. Escreveu pouco. Mas deixou algumas impressões. Quando perguntado sobre a sua entrada na escola, respondeu:

"Contaram para mim que eu chorei muito. Chorei o dia inteiro. Não queria ficar lá. Mas me deixaram o dia todo" (MILOS).

Nas voláteis memórias, perdidas nas “brumas da primeira infância”, os outros é que contam, recontam, e são os donos dessa história (RICOUER, 2014, p. 171), pois já não há mais na lembrança o choro. Mas o recontar por outros fica gravado, porque, possivelmente, é para pôr em evidência que "menino não chora". É o delinear de uma educação em que o masculino prevalece. Cabe lembrar que "a história de nossa infância não é psiquicamente datada" (BACHELARD, 2009, p. 100).

No ensino fundamental, estudava perto de sua casa, numa escola pública. Assim, descreveu a escola:

"era tudo muito grande. Havia um pátio onde a gente brincava na hora do recreio. Na hora do recreio, a quadra ficava lotada. As crianças se misturavam: os do primeiro ano com os do quarto ano. Mas eu ficava com os meus colegas de sala e brincava o tempo todo" (MILOS).

Não se relacionava com alunos de outras séries, a não ser com os da sua turma. Mas o brincar, naqueles instantes - o recreio não dura uma hora - era o suficiente para recarregar as forças, o ânimo.

Vale lembrar que "todo comportamento vivido fora dos domínios do propósito ou da intencionalidade ocorre como válido em si mesmo. Se é vivido dessa maneira, é vivido no brincar" pois o recreio, como espaço do brincar, também é um espaço de jogos, enfim, é o espaço da existência (VERDEN-ZOLLER, 2004, p. 146).

Relatou-nos que

"já nessa época, gostava de desenhar, mas não me lembro de ter sido incentivado por algum professor. Sempre gostei de colorir" (MILOS). 
Sobre as suas relações com os professores do ensino fundamental, informou-nos que foram boas. E não discorreu sobre o assunto. A resposta foi simples: "boa".

O gosto pelo desenhar, pelo devaneio, por criar já constituia Milos desde o ensino fundamental. Os silêncios, os movimentos das águas, águas do real - as que vão da calmaria à tormenta - levam-nos a crer que foi nesse período que a criatividade de Milos despontou com intensidade: momento da "água que corre" na vida e que ele passou a observar esse movimento. A água "é um elemento transitório. É a metamorfose ontológica essencial entre o fogo e a terra (BACHELARD, 2013, p. 7)".

No ensino médio, já com quase quinze anos, foi brigão, e um adolescente rebelde e, sobre a instituição, complementou:

\begin{abstract}
"era uma instituição da rede pública. No primeiro ano, os portões do colégio ficavam abertos, permitindo a entrada e saída de alunos a qualquer hora durante horário de funcionamento da instituição. Do segundo ano em diante, após o horário da entrada, eram tolerados quinze minutos de atraso. Depois disso, os portões se fechavam e só eram abertos novamente no segundo tempo de aula, sendo fechado em definitivo atéo horário de saída. Essas novas regras foram devidas à mudança da direção".
\end{abstract}

Não nos revelou muito sobre esse adolescente rebelde e brigão, mas acreditamos que, nesse período da existência, em plena adolescência, o demonstrar força tem importância para o jovem. Sobre o brigar, sobre as lutas, quando essas "terminavam com sucesso, transferiam para o vencedor uma espécie de poder mágico, garantia de futuras vitórias"(CHEVALIER e GHEERBRANT, 2012, p. 566), pois a luta, assim, é uma forma de captação de poderes, dando ao vencedor um acréscimo de forças. Vale lembrar que não contou sua participação em brigas, embora, em conversas informais, tenha dito que brigou algumas vezes.

Quanto aos portões, é preciso ressaltar que "a porta simboliza o local de passagem entre dois estados, entre dois mundos, entre o conhecido e o desconhecido", e que a porta tem um valor dinâmico, psicológico, como se um convite para atravessar estivesse sendo feito "(CHEVALIER e GHEERBRANT, 2012, p. 734).

Quando perguntado sobre as melhores e as piores lembranças desse período, respondeu:

"as amizades criadas ao longo dos anos, estudando na instituição, tanto entre alunos como entre alunos e alguns professores. Essas são as melhores lembranças que tenho desse período. As piores lembranças são as brigas, havia muitas brigas durante o recreio e na saída. Praticamente, toda semana acontecia uma briga. Na época, isso não me incomodava muito, mas hoje considero lembranças ruins" (MILOS).

Os valores, já nessa época, estavam consolidados em Milos, por isso, a amizade desponta como uma lembrança boa - amizade com colegas de turma e com alguns professores - e as brigas como lembranças ruins - embora, como já mencionado, não nos 
tenha contado formalmente a sua participação nelas. Não entrou em detalhes sobre as amizades criadas ao longo dos três anos do ensino médio.

Quanto às suas disciplinas prediletas, no ensino médio, disse-nos que

"não existia uma predileta. Durante esse período, eu estudava mais por obrigação do que por prazer. Entretanto, me familiarizei mais com história e geografia, porque os professores viajavam na matéria. Essas eram as matérias que eu absorvia com mais facilidade".

Se estudava mais por obrigação, como afirmou, trouxe-nos uma contradição - talvez porque nesse período estava se transformando, mudando a forma de pensar. A escolha das disciplinas, história e geografia, em conversas informais, se deu porque os professores filosofavam - 'viajavam', isto é, entravam em devaneios -, segundo suas palavras. Talvez esse fato de filosofar, de pensar a história e a geografia, como disciplinas que interagem com outras, é que lhe tenha fornecido base para ter consciência sobre o ato educativo e da necessidade dele.

Quanto ao relacionamento com os professores, informou-nos que

"era um bom relacionamento, sem nenhuma intimidade. Alguns professores se tornaram amigos, outros não, mas nenhum deles desgostava de mim e vice-versa" (MILOS).

Mais uma vez, ficou vaga a impressão que nos deixou por escrito, e não tivemos tempo para pedir uma explicação mais detalhada sobre isso. Mas trouxe-nos uma imagem, entre a calmaria e a tormenta das águas: a de um narcisismo idealizante.

É perto da fonte, perto das águas, que nasce esse narcisismo idealizante, subestimado pela psicanálise clássica; no entanto, importante para uma psicologia da imaginação, pois, nem sempre, o narcisismo é neurotizante, pois desempenha

também um papel positivo na obra estética e, por transposições rápidas, na obra literária. A sublimação nem sempre é a negação de um desejo; nem sempre ela se apresenta como uma sublimação contra os instintos. Pode ser uma sublimação por um ideal. Então, Narciso já não diz: "amo-me como sou", mas sim "sou tal como me amo" (BACHELARD, 2013, p. 25).

Cabe lembrar que "esse narcisismo idealizante realiza, então, a sublimação da carícia. A imagem contemplada nas águas aparece como o contorno de uma carícia toda visual. Não tem a menor necessidade da mão acariciante" (BACHELARD, 2013, p. 25).

Milos é observador - e esse observador remete-nos a palavra contemplador. A sua forma de desenhar mostra a sua capacidade de perceber detalhes. Assim, disse em uma conversa informal:

"gosto mesmo é de desenhar, gosto da publicidade, gosto de mexer com a cabeça dos outros; às vezes pensam que eu estou dizendo ou desenhando uma coisa, mas na verdade é outra. Não falo nada para quem observa. Mas dou uma risadinha por dentro, porque também pode ter uma outra interpretação" (MILOS). 
Quando disse 'dou uma risadinha por dentro', pensamos no deus Hermes, não mais como impostor, mas como mensageiro dos deuses, que "é ao mesmo tempo, o deus do hermetismo e da hermenêutica, do mistério e da arte de decifrá-lo" (CHEVALIER e GHEERBRANT, 2012, p. 488). Enfim, é o astuto desperto em cena.

\title{
Algumas (de)cifrações
}

\author{
Que é necessário sair da ilha para ver a ilha, \\ que não nos vemos se não nos sairmos de nós... \\ José Saramago, 2013
}

Após imersões no aquífero semântico (DURAND, 2002) da narrativa autobiográfica, em busca de ilhas desconhecidas, dois pontos podem ser destacados: o despertar da reflexão do narrador e o estreitamento das relações entre discente e docente. No que diz respeito ao despertar da reflexão do narrador, acreditamos que quando nos contamos, ao fazer uma sondagem na alma, quando nos examinamos e nos percebemos como carregadores de pensamentos (de emoções alegres ou tristes), quando imergimos no mais profundo, entre luzes e sombras, quando percebemos que podemos emergir e recontar, um sentimento de liberdade nos invade - proporcionado por esse momento reflexivo. É nesse despertar que ouvimos a nós mesmos; entretanto, isso não seria possível se não saíssemos de nós mesmos. A narrativa autobiográfica promove esse "sair de nós mesmos". Quanto ao estreitamento das relações entre o discente (narrador) e o docente (ouvinte), cumpre destacar um ponto: a emoção estética. É por meio da emoção estética que descobrimos e que "aprendemos a conhecer o mundo e, principalmente, a natureza do mundo humano no qual a realidade se entrelaça com o imaginário e o imaginário com a realidade", descobrindo um pouco mais de si mesmo, da natureza do outro, do mundo das subjetividades (MORIN, 2017, p. 102).

Essa emoção estética, ocasionada pelo narrar, nos revela que "[...] real não está na saída nem na chegada: ele se dispõe para a gente é no meio da travessia" (ROSA, 1994, p. 85).

E no meio da travessia, já saindo da ilha para ver a ilha, saindo de nós mesmos para nos vermos, é que, talvez, surge a possibilidade de compreender que a narrativa autobiográfica reverbera na alma, pois Mnemosyne, presente, auxilia a travessia por esses mares já navegados.

Recebido em: 16/06/2020 e Aprovado em: 28/09/2020 


\section{Notas}

1 Marguerite Yourcenar afirmou sobre a poesia de Kaváfis: "é um dos mais célebres poetas da Grécia moderna; é também um dos maiores, o mais sutil em todo caso, o mais novo talvez, o mais nutrido, no entanto, da inesgotável substância do passado. In: KAVÁFIS, Konstatinos. Poemas. Rio de Janeiro: Nova Fronteira, 1982. p.118-119.

2 Pathos ou path é uma palavra grega que significa paixão, excesso, catástrofe, passagem, passividade, sofrimento, assujeitamento, sentimento e doença. O conceito filosófico foi criado por Descartes para designar tudo o que se faz ou acontece de novo. E se o conceito está ligado a padecer, pois o que é passivo de um acontecimento, padece deste mesmo. Portanto, não existe pathos senão na mobilidade, na imperfeição. Tal termo grego pode ser transliterado como patia, pata e pato para as línguas neolatinas e anglo-saxãs, sendo eles utilizados como prefixos e/ou sufixos na composição muitas terminologias. Disponível em : https://pt.wikipedia.org/wiki/ Pathos. Acessado em 18.10.2018. Na sua República, Platão pôs na boca de Sócrates a afirmação de que a alma humana era composta por três partes: uma que deseja, outra que raciociona e uma terceira, a que chamou thymos, sendo esta a fogosidade, o brio, o pundonor da personalidade, aquela parte que quer o reconhecimento dos outros, nas relações intersubjectivas, aquela parte que não quer o reconhecimento de coisas ou valores exteriores, no sentido econômico, mas o reconhecimento de coisas, valores, ideias ou ideais do íntimo da alma, a sua afirmação, aquilo que na linguagem jurídica se reconduz aos termos técnicos de honra e consideração. Disponível em: https://vickbest.blogspot.com/2005/05/alma-humana-o-thymos-justia-e-guerra.html Acessado em 18.10.2018.

3 O'Sefer ha-Zohar: o Livro do Esplendoré, sem sombra de dúvida, a obra principal e mais sagrada da Cabalá, a dimensão mística do judaísmo. Fonte inesgotável de sabedoria e conhecimento, seus ensinamentos e revelações se equiparam, em importância, aos da Torá e do Talmud. Disponível em: https://herancajudaica.wordpress. com/2012/06/30/o-que-e-o-zohar/. Acessado em 29.9.2018.

\section{Referências}

BACHELARD, Gaston. A poética do espaço. São Paulo: Martins Fontes, 1993.

. A poética do devaneio. São Paulo: Martins Fontes, 2009.

. A água e os sonhos. São Paulo: São Paulo: Martins Fontes, 2013.

BYNGTON, Carlos Amadeu Botelho. A construção amorosa do saber: o fundamento e a finalidade da Pedagogia Simbólica Junguiana. São Paulo: Religare, 2003.

CHEVALIER, Jean; GHEERBRANT, Alain. Dicionário de símbolos: mitos, costumes, gestos, formas, figuras, cores, números. 26. Ed. Rio de Janeiro: José Olympio, 2012.

CIRLOT, Juan-Eduardo. Dicionário de símbolos. São Paulo: 2. Ed. Editora Moraes, 1984.

DUCHASTEL, Alexandra. O caminho do imaginário: o processo de arte-terapia. São Paulo: Paulus, 2010.

DURAND, Gilbert. As estruturas antropológicas do imaginário: introdução à arquetipologia geral. 3. ed. São Paulo: Martins Fontes, 2002.

GUSDORF, Georges. Professores para quê? Para uma pedagogia da pedagogia. São Paulo: Martins Fontes, 2003. 
HALLIDAY, M.; McINTOSH, A ; STREVENS, P. As ciências linguísticas e o ensino da língua. Petrópolis, Vozes, 1974.

HILLMAN, James. O livro do Puer: ensaios sobre arquétipos do Puer Aeternus. São Paulo: Paulus, 1998. O pensamento do coração e a alma do mundo. Campinas: Verus, 2010.

JAPIASSU, Hilton. A pedagogia da incerteza. Rio de Janeiro: Imago, 1983.

KAVÁFIS, Konstatinos. Poemas. Rio de Janeiro: Nova Fronteira, 1982.

MARTIN, K. O livro dos símbolos: reflexões sobre imagens arquetípicas. Colonia: Tashen, 2012.

LARROSA, Jorge. Tremores. Belo Horizonte: Autêntica, 2015.

LE BRETON, D. Antropologia dos sentidos. Petrópolis: Vozes, 2016.

MAFFESOLI, Michel. O ritmo da vida: variações sobre o imaginário pós-moderno. Rio de Janeiro: Record, 2007.

MORIN, Edgar. A cabeça bem-feita: repensar a reforma, reformar o pensamento. Rio de Janeiro: Bertrand Brasil, 2000.

O método 3: o conhecimento do conhecimento. 4. ed. Porto Alegre: Sulina, 2012. Sobre a estética. Rio de Janeiro: Pró-saber, 2017.

RICOUER, Paul. Tempo e narrativa. São Paulo: Martins Fontes, 2010.

ROGERS, Carl. Liberdade para aprender. Belo Horizonte: Interlivros, 1977.

ROSA, J. Guimarães. Grande Sertão: Veredas. São Paulo: Nova Aguilar, 1994.

ROSSET, Clément. O princípio da crueldade. 2. Ed. Rio de Janeiro: Rocco, 2002.

SARAMAGO, José. O conto da ilha desconhecida. 9. ed. Alfragide/Portugal: Ed. Caminho, 2013.

TEIXEIRA, Maria Cecília Sanchez; ARAÚJO, Alberto Filipe. Gilbert Durand: imaginário e educação. Niterói: Intextexto, 2011.

VERDEN-ZOLLER, Gerda. O brincar na relação materno-infantil. Fundamentos biológicos da consciência de si mesmo e da consciência social. In: MATURANA, Humberto; VERDEN-ZÖLLER, Gerda. Amar e brincar: fundamentos esquecidos do humano. 2. Ed. São Paulo: Pallas Athena, 2009. 